\title{
Comparative transcription analysis and toxin production of two fluoroquinolone-resistant mutants of Clostridium perfringens
}

\author{
Sunny Park ${ }^{1,2}$, Miseon Park ${ }^{1}$ and Fatemeh Rafii ${ }^{{ }^{*}}$
}

\begin{abstract}
Background: Fluoroquinolone use has been listed as a risk factor for the emergence of virulent clinical strains of some bacteria. The aim of our study was to evaluate the effect of fluoroquinolone (gatifloxacin) resistance selection on differential gene expression, including the toxin genes involved in virulence, in two fluoroquinolone-resistant strains of Clostridium perfringens by comparison with their wild-type isogenic strains.

Results: DNA microarray analyses were used to compare the gene transcription of two wild types, NCTR and ATCC 13124, with their gatifloxacin-resistant mutants, NCTR ${ }^{R}$ and $13124^{R}$. Transcription of a variety of genes involved in bacterial metabolism was either higher or lower in the mutants than in the wild types. Some genes, including genes for toxins and regulatory genes, were upregulated in NCTR $R^{R}$ and downregulated in $13124^{R}$. Transcription analysis by quantitative real-time PCR (qRT-PCR) confirmed the altered expression of many of the genes that were affected differently in the fluoroquinolone-resistant mutants and wild types. The levels of gene expression and enzyme production for the toxins phospholipase $C$, perfringolysin $\mathrm{O}$, collagenase and clostripain had decreased in $13124^{R}$ and increased in NCTR ${ }^{R}$ in comparison with the wild types. After centrifugation, the cytotoxicity of the supernatants of $N C T R^{R}$ and $13224^{R}$ cultures for mouse peritoneal macrophages confirmed the increased cytotoxicity of $N C T R^{R}$ and the decreased cytotoxicity of $13124^{R}$ in comparison with the respective wild types. Fluoroquinolone resistance selection also affected cell shape and colony morphology in both strains.

Conclusion: Our results indicate that gatifloxacin resistance selection was associated with altered gene expression in two C. perfringens strains and that the effect was strain-specific. This study clearly demonstrates that bacterial exposure to fluoroquinolones may affect virulence (toxin production) in addition to drug resistance.
\end{abstract}

Keywords: Clostridium perfringens, Fluoroquinolone, Resistance, Toxin, Virulence

\section{Background}

Clostridium perfringens is commonly found in the gastrointestinal (GI) tract of humans, animals, soils, freshwater sediments and sewage. It can cause various diseases in humans, including food poisoning, antibiotic-associated diarrhea, sporadic diarrhea, internal abscesses, and gas gangrene and also various animal diseases [1-5]. C. perfringens strains all are prolific toxin producers and are classified

\footnotetext{
* Correspondence: Fatemeh.Rafii@fda.hhs.gov

${ }^{1}$ Division of Microbiology, National Center for Toxicological Research, US

Food and Drug Administration, Jefferson, AR, USA

Full list of author information is available at the end of the article
}

based on their toxin formation. Various C. perfringens toxins denature cellular components of mammalian cells and are implicated in virulence and pathogenicity. Among these toxins are $\alpha$-toxin (phospholipase C, PLC) and $\theta$-toxin (perfringolysin $\mathrm{O}, \mathrm{PFO}$ ), which are essential for gas gangrene pathogenesis. Other toxins or hydrolytic enzymes may be involved in destruction of connective tissue or spread of bacteria in infected tissues $[4,6,7]$. C. perfringens, although a commensal, can cause life threatening infections and is implicated in inflammatory bowel diseases [8-10]. In a survey of Clostridium species bacteremia, in a Canadian hospital between 2000-2006, C. perfringens was shown to have caused $42 \%$ of the

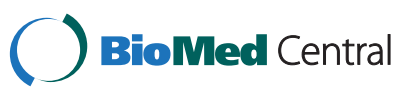


cases, which was more than any other Clostridium species [11]. It causes nearly a million cases of food borne illness each year in the United States [1]. Bacteria from the GI tract, including $C$. perfringens, may become resistant to fluoroquinolones used for treatment or prophylaxis of bacterial infections. Surveys of fluoroquinolone-resistant-anaerobes found ciprofloxacinresistant $C$. perfringens as early as 1992 among clinical isolates [12]. Although similar surveys have not been conducted in recent years, Gionchetti et al. [10] showed that treatment of patients with chronic treatmentresistant pouchitis with $1 \mathrm{~g}$ of ciprofloxacin for 15 days did not result in a statistically significant reduction in C. perfringens. One reason for fluoroquinolone resistance development is mutation in the fluoroquinolone target genes, gyrase ( $g y r A$ and $g y r B$ ) and topoisomerase IV (parC and parE) [13]. Because fluoroquinolones are DNA-damaging agents, they may also induce the SOS response [14-16] that results in expression of DNA repair genes, which may lead to phenotypic changes in fluoroquinolone-resistant strains [17-20]. Excessive use of fluoroquinolones has been attributed to the emergence of virulent strains of bacteria [21-24]. Clostridium difficile strain NAP1/027, which emerged in 2002 in Canada and the USA, now has spread to most parts of Europe [22]. In a gut model, higher rates of spore germination and levels of toxin production were observed in two ribotypes of $C$. difficile that were exposed to three different fluoroquinolones [24]. Wide dissemination of virulent fluoroquinolone-resistant strains of Escherichia coli has been reported in East Asia [25]. Other reports, sometimes conflicting, show either increased or decreased virulence in fluoroquinolone-resistant clinical isolates of bacteria [26-28]. Previously we showed that different $C$. perfringens strains rapidly developed resistance, even to high potency fluoroquinolones, and that resistant strains had various mutations in the fluoroquinolone target genes [29]. In addition, the production of some enzymes was altered in some resistant mutants [30,31]. One gatifloxacin-resistant strain, NCTR, had increased levels of $\alpha$-toxin (phospholipase C, PLC) and $\theta$-toxin (perfringolysin $\mathrm{O}, \mathrm{PFO}$ ) [30]. These results point to global changes in the expression of various genes in gatifloxacin- resistant strains and to the need for further study. In this study, we have used genomic analysis (microarray and QRT-PCR) to compare the changes in gene expression in two gatifloxacin-resistant strains of $C$. perfringens following fluoroquinolone resistance selection, and have compared the toxin production and cytotoxicity of the strains. Strain NCTR was selected because of enhanced production of PLC and PFO by its gatifloxacin resistant mutant and was compared with strain ATCC 13124, which is a gangrene isolate whose genomic sequence is known, and its gatifloxacin resistant mutant $13124^{\mathrm{R}}$ has the same mutation in $g y r A$ as $\mathrm{NCTR}^{\mathrm{R}}$.

\section{Methods}

\section{Growth of bacterial strains}

Wild types and gatifloxacin-resistant mutants of $C$. perfringens strains ATCC 13124 and NCTR [29] were used in this study. The development of these mutants (Gat-13124-10 and Gat-NCTR- 10) was described previously [29]. Both mutants have stable mutations in target genes and will be referred to as $13124^{R}$ and $N C T R^{R}$ in this study. Both mutants had a mutation in $\operatorname{gyr}$ (G81C, $\mathrm{D} 87 \mathrm{Y}), 13124^{\mathrm{R}}$ had mutation in $\operatorname{gyrB}$ (A431S) and parC (S89I), and $\mathrm{NCTR}^{\mathrm{R}}$ had a mutation in parE (E486K). The bacteria were grown anaerobically under an atmosphere of $85 \% \mathrm{~N}_{2}, 10 \% \mathrm{CO}_{2}$, and $5 \% \mathrm{H}_{2}$ at $37^{\circ} \mathrm{C}$ in brain heart infusion (BHI) broth (Remel, Lenexa, KS) with vitamin $\mathrm{K}(1 \mu \mathrm{g} / \mathrm{ml})$, hemin $(5 \mu \mathrm{g} / \mathrm{ml})$, and L-cysteine $(5 \mu \mathrm{g} / \mathrm{ml}$ ) (Sigma Chemical Co., St. Louis, MO) [29]. No antibiotics were added.

\section{Preparation of RNA}

Early exponential (2.5-3.0 h) growth phase cultures of all four strains, grown in BHI under identical anaerobic conditions, were used to isolate RNA for microarrays. Cells from $100-\mathrm{ml}$ cultures were harvested by centrifugation $\left(15,000 \times g, 10 \mathrm{~min}, 4^{\circ} \mathrm{C}\right)$, washed with $10 \mathrm{mM}$ Tris and $1 \mathrm{mM}$ EDTA ( $\mathrm{pH} 8.0$ ), and suspended in $1 \mathrm{ml}$ of buffer containing $10 \mathrm{mg} / \mathrm{ml}$ of lysozyme (Sigma). The mixtures were incubated for $10 \mathrm{~min}$ at room temperature and centrifuged $\left(15,000 \times g, 10 \mathrm{~min}, 4^{\circ} \mathrm{C}\right)$. The samples were suspended in $0.5 \mathrm{ml} \mathrm{TE}$ ( $10 \mathrm{mM}$ Tris, $1 \mathrm{mM}$ EDTA) and mixed with $5 \mathrm{ml}$ of RNA-Bee isolation reagent from TEL-TEST, Inc. (Friendship, TX). After addition of $1 \mathrm{ml}$ chloroform to the mixture, the samples were incubated on ice for $30 \mathrm{~min}$ and centrifuged $(15,000 \times g$, $\left.30 \mathrm{~min}, 4^{\circ} \mathrm{C}\right)$. The clear phases were harvested, added to an equal volume of isopropanol and centrifuged to pellet the RNA. The RNA was further purified using an RNeasy $^{\mathrm{R}}$ Mini Kit (50) from QIAGEN, Inc. (Valencia, $\mathrm{CA}$ ), according to the instructions provided with the kit. After RNA extraction and purification, contaminating DNA was removed using $10 \mathrm{U}$ of RNase-free DNase 1 (Boehringer Mannheim, Ingelheim, Germany). The quantity and quality of total RNA was determined using a Nanodrop ND-1000 spectrophotometer (NanoDrop Technology, Wilmington, DE). RNA purification steps for real-time PCR (qRT- PCR) were essentially the same. The RNA was stored at $-80^{\circ} \mathrm{C}$ and used within a week to avoid degradation of RNA. RNA was extracted from three different cultures of each strain for microarray analysis and qRT-PCR. 


\section{Probe design for microarrays}

The probes were designed by Biodiscovery LLC, Ann Arbor, MI (http://www.mycroarray.com/) from the sequences of $C$. perfringens strains 13 (CPE) and ATCC 13124 (CPF in http://www.ncbi.nlm.nih.gov), using OligoArray v 3.1 (http://berry.engin.umich.edu). The designs of microarrays were submitted to MIAMExpress and can be accessed at the following links: for strain 13124, [http:// www.ebi.ac.uk/arrayexpress/arrays/A-MEXP-2008], and for strain NCTR, at [http://www.ebi.ac.uk/arrayexpress/arrays/ A-MEXP-2027].

\section{Microarray hybridization}

The microarrays were hybridized by Biodiscovery LLC to fluor-labeled RNA at $60^{\circ} \mathrm{C}$ for at least $16 \mathrm{~h}$ in 2gasket slides and commercial hybridization chambers (Agilent, Santa Clara, CA) while being rotated ( $4 \mathrm{rpm})$ in a hybridization incubator. The hybridization solution contained $6 \times \operatorname{SSPE}\left(1 \mathrm{M} \mathrm{NaCl}, 50 \mathrm{mM} \mathrm{NaH} \mathrm{PO}_{4}\right.$, $50 \mathrm{mM} \mathrm{Na}{ }_{2} \mathrm{HPO}_{4}, 3 \mathrm{mM}$ EDTA, pH 6.7), $1 \mu \mathrm{g} / \mu \mathrm{l}$ acetylated BSA, $1 \mu \mathrm{g} / \mu \mathrm{l}$ herring sperm DNA (Promega, Madison,WI), 0.01\% Tween 20 (Sigma) and $10 \mu \mathrm{g}$ template RNA per array. The hybridized arrays were washed twice in $6 \times \operatorname{SSPE}$ for $5 \mathrm{~min}$ at $60^{\circ} \mathrm{C}$, once in $1 \times$ SSPE for $5 \mathrm{~min}$ at $20^{\circ} \mathrm{C}$, and once in $0.25 \times \mathrm{SSPE}$ at $20^{\circ} \mathrm{C}$ for $1 \mathrm{~min}$, and then were spun dry in a microarray highspeed centrifuge (ArrayIT, model MHC). The arrays were scanned in an Axon 4000B scanner (Molecular Devices Sunnyvale, California), controlled by GenePixPro software (v 6.1.0.4). The resulting images were quantified with the same software and the results were archived in the gpr file format. The mean expression of each gene for the mutant was divided by the mean expression of the same gene for the wild type. Those genes for which the values were $\geq 1.5$ were considered upregulated in the mutant, and the genes for which this value was $\leq 0.6$ were considered downregulated in the mutant. The genes that were upregulated or downregulated were selected for further RT-PCR analysis.

\section{Quantitative real-time PCR (qRT-PCR)}

Primers used for qRT-PCR are listed in Additional file 1. The genes that were upregulated in one mutant and downregulated in the other mutant, in comparison with their respective wild types, by microarray analysis were selected to design primers. Some genes involved in regulation of transcription were also selected. The sequence of C. perfringens ATCC 13124 (http://www.ncbi.nlm.nih. gov/nuccore/CP000246.1) was used to design primers that generated PCR amplicons of 100-150 bp in length via the default setting of "Primer 3 Input software" (http://frodo.wi.mit.edu/primer3). For cDNA template synthesis, SuperScriptTM III First-Strand Synthesis SuperMix (Invitrogen, Carlsbad, CA) was used. For
qRT-PCR, SYBR ${ }^{\circledR}$ GreenER ${ }^{T M}$ qPCR SuperMix (Invitrogen) was used. The reaction mixtures were prepared on ice according to the manufacturer's instructions. Each reaction contained $2 \times$ Express SYBR Green ER qRT-PCR universal mix, $25,2.5$, or $0.25 \mathrm{ng}$ of the cDNA template, and $2 \mu \mathrm{M}$ each of the forward and reverse primers. The amplification was performed using a CFX96 Real-Time PCR detection system (Bio-Rad, Hercules, CA) and the following protocol: $50^{\circ} \mathrm{C}$ for $10 \mathrm{~min}, 95^{\circ} \mathrm{C}$ for $8.5 \mathrm{~min}$ to inactivate uracil DNA glycosylase and activate DNA polymerase, followed by 40 cycles of $95^{\circ} \mathrm{C}$ for $15 \mathrm{~s}$ and $60^{\circ} \mathrm{C}$ for $1 \mathrm{~min}$ to amplify cDNA. Melting curves were monitored at $65-95^{\circ} \mathrm{C}\left(1^{\circ} \mathrm{C}\right.$ per 5 s) to detect any nonspecific amplification. Either 25, 2.5, or $0.25 \mathrm{ng}$ of each 16S rRNA gene was amplified as a reference RNA of equivalent size for normalization [32]. Reaction mixtures without reverse transcriptase, for detecting genomic DNA contamination, and reaction mixtures without templates, for detecting nucleic acid contamination of reagents and tubes, were included as controls. Each PCR reaction was run in triplicate for each type of RNA isolated from three different cultures of each wild type or mutant. The relative level of mRNA expression was calculated by the $2^{-\Delta \Delta C}$ T method according to Real-Time PCR Application Guide (Additional file 2).

\section{Detection of phospholipase C (PLC) and perfringolysin O (PFO)}

PLC and PFO activities were measured according to the methods previously described $[7,30,33]$. The hemoglobin release from red blood cells in the presence of perfringolysin buffer was measured to detect perfringolysin $\mathrm{O}$ (PFO) according to the method of O'Brien and Melville [33]. The increase in turbidity of lecithin in egg yolk emulsion or the release of nitrophenol from $\mathrm{O}$-(4-nitrophenyl-phosphoryl) choline as the result of hydrolysis by PLC was used to measure phospholipase C (PLC) activity $[7,30]$.

\section{Collagenase assay}

The amounts of collagenase in the mutants and wild types were calculated by the method of Awad et al. [34] by measuring the amount of dye released from Azo Dye Impregnated Collagen (azocoll) (Sigma). Azocoll powder was washed and resuspended in $0.2 \mathrm{M}$ of borate buffer (pH 7.2) containing $0.15 \mathrm{M} \mathrm{NaCl}, 20 \mu \mathrm{M} \mathrm{ZnCl}$ and $5 \mathrm{mM} \mathrm{CaCl}_{2}$ to a final concentration of $5 \mathrm{mg}$ azocoll per ml. Next, $100 \mu \mathrm{l}$ of the filter-sterilized supernatants of centrifuged wild types and mutants were added to $400 \mu \mathrm{l}$ of azocoll solution and the mixtures were incubated for $2 \mathrm{~h}$ at $37^{\circ} \mathrm{C}$. Following centrifugation at $16,100 \times g$, the released dye was measured by the absorbance at $550 \mathrm{~nm}$. 


\section{Assay for clostripain}

A clostripain substrate, $N$-carbobenzoxy-L-arginine $p$ nitroanilide (Z-Arg-pNA) (Bachem Americas, Torrance, $\mathrm{CA})$, was used for measuring the amounts of clostripain in the supernatants of wild types and mutants [35]. The filter-sterilized supernatant from each centrifuged strain was incubated overnight at $4{ }^{\circ} \mathrm{C}$ in a buffer containing dithiothreitol to reduce the thiol group of the cysteine residues of clostripain. Next, $20 \mu \mathrm{l}$ of the sample was added to the $300 \mu \mathrm{l}$ buffer containing $2 \mathrm{mM} \mathrm{CaCl}_{2}$ and $260 \mathrm{mM}$ of Z-Arg-pNA. The kinetics software of the spectrophotometer was programmed to measure the absorbance at $410 \mathrm{~nm}$ every $\mathrm{min}$ for $30 \mathrm{~min}$. The amount of cleavage of Z-Arg-pNA was measured and the enzyme units were calculated. One unit was defined as the amount of enzyme that hydrolyzed $1.0 \mu \mathrm{mol}$ of Z-Arg-pNA per min [35].

\section{Detection of sialidase}

Sialidase activity was measured in filter-sterilized supernatants of centrifuged cultures of mutants and wild types, using 4 mM 5-bromo-4-chloro-3-indolyl- $\alpha-D-N$-acetylneuraminic acid, sodium salt [36]. The assay reaction was performed in 96-well plates by addition of the supernatant to wells containing the substrates, according to a procedure recommended by Sigma for measuring recombinant $C$. perfringens neuraminidase. The kinetics software was programmed to measure the absorbance at $595 \mathrm{~nm}$.

\section{Hyaluronidase detection}

The amounts of hyaluronidase in the filter-sterilized supernatants of centfifuged wild types and mutants were quantified by measuring the degradation of hyaluronic acid. Bovine hyaluronic acid (Sigma) was dissolved in acetate buffer (200 mM sodium acetate, $150 \mathrm{mM} \mathrm{NaCl}$, $\mathrm{pH}$ 6.0) to a final concentration of $1 \mathrm{mg} / \mathrm{ml} .100 \mu \mathrm{l}$ of the hyaluronic acid solution was incubated with $400 \mu \mathrm{l}$ of the filter-sterilized supernatants of the wild types and mutants for $30 \mathrm{~min}$ at $37^{\circ} \mathrm{C}$. One $\mathrm{ml}$ of a solution containing $2 \% \mathrm{NaOH}$ and $2.5 \%$ cetramide (cetyltrimethylammonium bromide, Sigma) was added to the reaction mixture. The turbidity of the insoluble complex formed between cetramide and hyaluronic acid was measured at $400 \mathrm{~nm}$ [37]. The reduction in turbidity, reflecting the decrease in hyaluronic acid because of the activity of hyaluronidase, was calculated by comparing the turbidities of samples containing the supernatant of each culture with controls containing BHI alone. The enzyme assays for all the enzymes were performed three times from three different cultures of each strains.

\section{Cytotoxicity of $C$. perfringens supernatants for macrophages}

Macrophages were obtained from C57BL/6 male mice, 4-6 weeks old, which had ad libitum access to food and water. The maintenance, handling and sacrifice of mice were according to procedures approved by the NCTR Institutional Animal Care and Use Committee. Resident mouse peritoneal macrophages were harvested by peritoneal lavage, using $4 \mathrm{ml}$ of supplemented DMEM medium, containing $5 \%$ heat-inactivated fetal bovine serum, $100 \mu \mathrm{g} / \mathrm{ml}$ streptomycin sulfate, 100 units $/ \mathrm{ml}$ penicillin G, $110 \mathrm{mg} / \mathrm{L}$ sodium pyruvate, and $2 \mathrm{mM}$ glutamine. Red blood cells were removed by hypotonic lysis. The peritoneal exudate cells were washed once with DMEM, plated and incubated at $37^{\circ} \mathrm{C}$ in a humidified atmosphere of $5 \% \mathrm{CO}_{2}$ [33]. Floating cells were removed and the macrophages were incubated in DMEM, containing $10 \% \mathrm{BHI}$ or filter-sterilized supernatants of overnight cultures of wild types and mutants, for $18 \mathrm{~h}$ at $37^{\circ} \mathrm{C}$ in a $\mathrm{CO}_{2}$ incubator. A CytoTox $96^{\circledR}$ Non-Radioactive Cytotoxicity Assay Kit (Promega) was used to measure the toxicity of the mutants and wild type cultures for macrophages. The cytotoxicity of each absorbance unit of the cells of different strains was calculated by the amount of lactate dehydrogenase (LDH) released from the macrophages. The differences in cytotoxicity due to the mutants and wild types were assessed using Student's $t$-test.

\section{Morphological examination}

Colony morphology of the strains was compared after overnight growth on BHI plates. For cellular morphology, log phase grown cells were Gram stained and examined under the light microscope.

\section{DNA sequencing}

Several regulatory and toxin genes and enzymes from wild types and mutants were amplified and sequenced as previously described [29].

\section{Results}

Transcriptional analysis by DNA microarray

Using the genome sequences of $C$. perfringens strain 13 and strain ATCC 13124, microarray probes were designed for genome-wide transcriptional analysis of two fluoroquinolone-resistant C. perfringens strains, $\mathrm{NCTR}^{\mathrm{R}}$ and $13124^{\mathrm{R}}$, and their wild types. Microarray analysis showed that a variety of genes were upregulated $(\geq 1.5$ fold) or downregulated ( $\leq 1.5$ fold) in the fluoroquinoloneresistant strains. The altered genes with known functions that were affected in both strains as the results of fluoroquinolone resistance selection are grouped in Tables 1, 2, 3 according to the classification used by the Institute for Genomic Research (http://www.jcvi.org/). In addition, the microarray detected alterations of many genes, for which the function is not known, which are listed as hypothetical proteins in the GenBank. Some of these were upregulated manyfold in both resistant strains, especially in $13124^{\mathrm{R}}$. 
Table 1 Microarray and qRT-PCR analysis of the genes that were differentially affected in the gatifloxacin resistant mutants, NCTR ${ }^{R}$ and $13124^{R}$

\begin{tabular}{|c|c|c|c|c|c|}
\hline \multirow[t]{2}{*}{ Gene ID and name } & \multirow[t]{2}{*}{ Function } & \multicolumn{2}{|c|}{$\begin{array}{l}\text { Microarray } \\
\mathrm{mt} / \mathrm{wt}\end{array}$} & \multicolumn{2}{|c|}{$\begin{array}{l}\text { qRT-PCR } \\
\mathrm{mt} / \mathrm{wt}\end{array}$} \\
\hline & & NCTR & ATCC 13124 & NCTR & ATCC 13124 \\
\hline \multicolumn{6}{|l|}{ Cell envelope } \\
\hline CPE1089 CPF_1345 & putative membrane protein & 4.3 & -2.1 & 7.3 & -2.8 \\
\hline CPE0162 CPF_0155 (pfoR) & putative membrane protein & 2.6 & -4.0 & 3.3 & -3.5 \\
\hline CPE0251 CPF_0244 & putative lipoprotein & 5.0 & -2.4 & 2.0 & -3.5 \\
\hline CPE0278 CPF_0274 (sagA) & sagA protein & 1.1 & -2.4 & 4.7 & -2.6 \\
\hline CPE0714 CPF_0710 & putative monogalactosyl-diacylglycerol synthase & 2.4 & -2.4 & 7.6 & 6.3 \\
\hline
\end{tabular}

\section{Cellular processes}

\begin{tabular}{|c|c|c|c|c|c|}
\hline CPE0036 CPF_0042 (p/c) & phospholipase C & 4.8 & -6.8 & 1.9 & -3.3 \\
\hline CPE0846 CPF_0840 (cloS1) & a-clostripain & 17.3 & -15.6 & 8.3 & -1143 \\
\hline CPE1474 CPF_1725 (hlyC) & hemolysin III & 3.2 & -1.8 & 15.1 & -2.6 \\
\hline CPE0163 CPF_0156 (pfoA) & perfringolysin $\mathrm{O}$ & 3.6 & -71.4 & 6.4 & -462 \\
\hline CPE0782 CPF_0784 (ahpC) & alkyl hydroperoxide reductase-C subunit & 10.3 & -2.6 & 13.4 & -12.6 \\
\hline CPE1092 CPF_1348 (pac) & choloylglycine hydrolase family protein & 1.7 & -2.5 & 25.7 & -1.7 \\
\hline \multicolumn{6}{|l|}{ Energy metabolism } \\
\hline CPE0778 CPF_0780 & oxidoreductase, FDA-binding & 4.8 & -2.8 & 85 & 2.6 \\
\hline CPE1299 CPF_1505 (eno) & enolase & 3.5 & -1.6 & 11.9 & -1.9 \\
\hline CPE2058 CPF_2315 (gadB) & glutamate decarboxylase & 31.9 & -3.5 & 20.0 & -3.4 \\
\hline CPE2437 CPF_2747 (nrdH) & glutaredoxin-like protein, YruB-family & 3.8 & -2.5 & 4.8 & -11.0 \\
\hline CPE2551 CPF_2875 (g/pA) & probable glycerol-3-phosphate dehydrogenase & 0.8 & -2.5 & 1.3 & -0.1 \\
\hline \multicolumn{6}{|c|}{ Purines, pyrimidines, nucleotides, and nucleosides } \\
\hline CPE2276 CPF_2558 (guaB) & inosine-5'-monophosphate dehydrogenase & 9.2 & -3.6 & 30.3 & -1.5 \\
\hline CPE2622 CPF_2958 (purA) & adenylosuccinate synthetase & 4.3 & -1.9 & 14.8 & -0.8 \\
\hline \multicolumn{6}{|l|}{ Protein fate } \\
\hline CPE0173 CPF_0166 (ColA) & collagenase & 9.9 & -4.7 & 8.5 & -2.7 \\
\hline CPE2323 CPF_2632 (pepF) & probable oligoendopeptidase $F$ & 2.7 & -2.0 & 11.6 & 4.3 \\
\hline CPE1205 CPF_1002 (abgB) & amidohydrolase family protein & 1.9 & -4.3 & 67.4 & -1.6 \\
\hline \multicolumn{6}{|l|}{ Regulatory functions } \\
\hline CPE0073 CPF_0069 & transcription antiterminator & 2.1 & -5.0 & 1.9 & -2.6 \\
\hline CPE0759 CPF_0753 & putative regulatory protein & 1.5 & -5.4 & 3.3 & 0.6 \\
\hline CPE1533 CPF_1784 (scrR) & sucrose operon repressor & 1.7 & -2.8 & 132 & -1.5 \\
\hline CPE2035 CPF_2292 (hrCA) & heat-inducible transcription repressor HrcA & 2.3 & -2.9 & 9.5 & 5.5 \\
\hline CPE2363 CPF_2673 & two-component sensor histidine kinase & 2.1 & -3.0 & 16.1 & 2.7 \\
\hline
\end{tabular}

\section{Transport and binding proteins}

\begin{tabular}{|c|c|c|c|c|c|}
\hline CPE1240 CPF_1450 (mgtE) & magnesium transporter & 8.6 & -1.7 & 5.2 & -2.6 \\
\hline CPE1300 CPF_1507 (gadC) & glutamate:y-aminobutyrate antiporter family protein & 9.6 & -2.7 & 17.1 & -7.3 \\
\hline CPE1505 CPF_1756 (uraA) & uracil transporter & 3.8 & -2.7 & 3.9 & -4.6 \\
\hline CPE0075 CPF_0070 & $\mathrm{N}$-acetyl glucosamine-specific & 1.4 & -14.3 & 1.8 & ND \\
\hline CPE0707 CPF_0703 & ABC transporter, ATP-binding protein & 1.5 & -3.2 & 5.2 & 2.9 \\
\hline CPE0761 CPF_0756 (gltP) & proton/sodium-glutamate symporter & 1.5 & -4.2 & 4.6 & 0.9 \\
\hline CPE1371 CPF_1621 & sodium:neurotransmitter symporter family protein & 1.8 & -4.0 & 15.2 & 2.7 \\
\hline CPE2084 CPF_2341 (modB) & molybdate $A B C$ transporter, permease protein & 1.8 & -2.5 & 10.8 & 2.0 \\
\hline CPE2343 CPF_2652 (male) & putative maltose/maltodextrin $A B C$ transporter & 2.9 & 1.3 & 3.8 & -2.1 \\
\hline \multicolumn{6}{|l|}{ Unknown functions } \\
\hline CPE0183 CPF_0176 & nitroreductase family protein & 1.0 & -4.8 & 2.9 & -1.1 \\
\hline
\end{tabular}


Table 1 Microarray and qRT-PCR analysis of the genes that were differentially affected in the gatifloxacin resistant mutants, NCTR $^{R}$ and $13124^{R}$ (Continued)

\begin{tabular}{|c|c|c|c|c|c|}
\hline CPE1172 CPF_1375 & haloacid dehalogenase & 2.1 & -2.4 & 20.6 & -1.7 \\
\hline CPE1784 CPF_2038 (nifU) & NifU family protein & 1.3 & -2.5 & 6.4 & -1.5 \\
\hline CPE2448 CPF_2758 & PSP1 domain-containing protein & 1.0 & -2.4 & 5.5 & -1.9 \\
\hline
\end{tabular}

All of the data are the means of three different experiments.

The genes that were differentially affected in the resistant strains are shown in Table 1. Many of these genes were generally upregulated in $\mathrm{NCTR}^{\mathrm{R}}$ and downregulated in $13124^{\mathrm{R}}$. The common genes that were upregulated in one or both mutants are in Table 2 and those that were downregulated in both are in Table 3. Some genes involved in amino acid biosynthesis, protein synthesis, fatty acid synthesis, and phospholipid metabolism were mostly upregulated in $13124^{R}$. Some genes for putative membrane proteins were upregulated in either one (Table 1) or both mutants (Table 2). The ATP synthase and potassium transporter genes were upregulated in both mutants (Table 2). Some of the genes involved in purine, pyrimidine, nucleotide, and nucleoside transport and metabolism were upregulated in both mutants and some were downregulated in both mutants (Tables 2 and 3). Several transcriptional regulators, transporters and kinases also were downregulated in one or both mutants (Tables 1 and 3). Resistance selection also affected the expression of genes involved in virulence (phospholipase $\mathrm{C}$, perfringolysin $\mathrm{O}$, collagenase, hemolysin III and $\alpha$-clostripain). Surprisingly, these genes were upregulated in strain $\mathrm{NCTR}^{\mathrm{R}}$ and downregulated in strain $13124^{\mathrm{R}}$.

\section{Validation of DNA microarray data by qRT-PCR}

To verify that fluoroquinolone resistance selection indeed had different effects on the expression of some of the genes in C. perfringens, the transcription of the genes that were generally upregulated or unchanged in $\mathrm{NCTR}^{\mathrm{R}}$ and downregulated in $13124^{\mathrm{R}}$ was measured by qRTPCR (Table 1). Real-time PCR verified the upregulation of all of the genes that were tested in $\mathrm{NCTR}^{\mathrm{R}}$ and downregulation of a majority of the genes that were downregulated in $13124^{\mathrm{R}}$. qRT-PCR was also performed on the genes that are reported to have regulatory functions (Table 4). virR, virS, vrr, virX and others were all upregulated in $\mathrm{NCTR}^{\mathrm{R}}$ by at least twofold. In strain $13124^{\mathrm{R}}$, virX was downregulated more than twofold, but $v r r$ also was substantially downregulated. Among the genes whose expression was altered by fluoroquinolone resistance selection were phospholipase C (PLC), perfringolysin $\mathrm{O}$ (PFO), $\alpha$-clostripain, hemolysin III, and collagenase. Both microarray analysis and qRT-PCR showed upregulation of these genes in $\mathrm{NCTR}^{R}$ and downregulation in $13124^{\mathrm{R}}$. Both microarray and qRT-PCR showed downregulation of the sialidase gene, nanI, in $\mathrm{NCTR}^{\mathrm{R}}$ and upregulation of this gene in $13124^{\mathrm{R}}$.

\section{Toxin production in the mutants and wild types}

The quantities of several enzymes that are implicated in bacterial virulence were measured for each absorbance unit of cells of wild types and mutants of both strains (Figures 1 and 2). The production of phospholipase $\mathrm{C}$ (PLC), perfringolysin O (PFO), collagenase, clostripain, and sialidase were all affected in the resistant mutant. Strain $13124^{\mathrm{R}}$ produced less PLC and PFO than the wild type. In contrast, as previously reported [30], the production of both enzymes increased in $\mathrm{NCTR}^{\mathrm{R}}$. Collagenase and clostripain production also were similarly affected by fluoroquinolone resistance selection, but the most dramatic effect was for perfringolysin O (PFO) in ATCC 13214, which was totally inhibited in $13124^{\mathrm{R}}$. However, sialidase had increased in $13124^{\mathrm{R}}$ but decreased in $\mathrm{NCTR}^{\mathrm{R}}$. Hyaluronidase was not significantly affected. The alterations in the production of PLC, PFO, collagenase and clostripain in both strains reflected the alteration of gene expression for these enzymes, as shown by microarray and qRT-PCR.

\section{Cytotoxic effects on mouse peritoneal macrophages}

To investigate if the changes in the expression levels of toxin genes in the fluoroquinolone resistant mutants affected cytotoxicity for phagocytes, cytotoxicity assays were performed by incubating mouse peritoneal macrophages with cell-free filtrates of the centrifuged bacterial cultures. The levels of cytotoxicity were compared by measuring the amount of lactate dehydrogenase (LDH) released from the lysed macrophages. The relative cytotoxicity was about threefold lower $(P=$ 0.0131 ) in $13124^{\mathrm{R}}$ than in ATCC 13124 (Figure 3). The supernatant of $\mathrm{NCTR}^{\mathrm{R}}$ showed about 1.4-fold higher cytotoxicity than that of NCTR. Microscopic observation also indicated that macrophages treated with bacterial culture media from ATCC 13124 and $\mathrm{NCTR}^{\mathrm{R}}$ were rounded off and detached from the surface (Additional file 3).

\section{Morphological examination}

Gram staining of log phase cultures showed that gatifloxacin resistance selection affected the shape of cells (Additional file 4). As expected, the Gram reaction was positive 


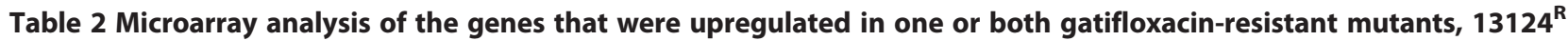
and NCTR ${ }^{R}$

\begin{tabular}{|c|c|c|c|c|}
\hline \multirow{2}{*}{\multicolumn{2}{|c|}{ Gene ID and name }} & \multirow[t]{2}{*}{ Function/Similarity } & \multicolumn{2}{|c|}{ Microarray (mt/wt) } \\
\hline & & & NCTR & ATCC 13124 \\
\hline \multicolumn{5}{|c|}{ Amino acid biosynthesis } \\
\hline CPE1520 & CPF_1772 (ilvE) & branched-chain amino acid aminotransferase & 1.1 & 2.6 \\
\hline CPE1905 & CPF_2161 (dapA) & dihydrodipicolinate synthase & 1.0 & 1.9 \\
\hline \multicolumn{5}{|c|}{ Cell envelope } \\
\hline CPE0492 & CPF_0465 & capsular polysaccharide biosynthesis protein & 6.5 & 1.9 \\
\hline CPE0495 & CPF_0468 & UDP-glucose/GDP-mannose dehydrogenase family & 3.5 & 2.4 \\
\hline CPE2059 & CPF_2316 & putative membrane protein & 7.1 & 3.2 \\
\hline CPE2079 & CPF_2336 & putative membrane protein & 14.2 & 2.1 \\
\hline CPE0785 & CPF_0787 & putative membrane protein & 2.3 & 2.1 \\
\hline \multicolumn{5}{|c|}{ Energy metabolism } \\
\hline CPE2186 & CPF_2451 (atpE) & ATP synthase epsilon subunit & 3.3 & 2.9 \\
\hline CPE2187 & CPF_2452 (atpB) & ATP synthase beta subunit & 3.6 & 2.2 \\
\hline CPE2189 & CPF_2454 (atpA) & ATP synthase alpha subunit & 4.2 & 2.4 \\
\hline CPE2190 & CPF_2455 (atpH) & ATP synthase delta subunit & 1.9 & 2.1 \\
\hline CPE2191 & CPF_2456 (atpF) & ATP synthase B chain & 2.2 & 2.3 \\
\hline CPE2192 & CPF_2457 (atpL) & ATP synthase $C$ chain & 3.6 & 2.3 \\
\hline \multicolumn{5}{|c|}{ Fatty acid and phospholipid metabolism } \\
\hline CPE1068 & CPF_1324 (fabH) & 3-oxoacyl-(acyl-carrier-protein) synthase III & 2.2 & 4.7 \\
\hline CPE1069 & CPF_1325 (fabD) & malonyl CoA-acyl carrier protein transacylase & 1.1 & 3.6 \\
\hline CPE1071 & CPF_1327 (fabF) & 3-oxoacyl-(acyl-carrier-protein) synthase II & 1.3 & 3.8 \\
\hline CPE1072 & CPF_1328 (accB) & acetyl-CoA carboxylase, biotin carboxyl carrier & 0.9 & 4.0 \\
\hline CPE1073 & CPF_1329 (fabZ) & beta-hydroxyacyl-(acyl-carrier-protein) dehydratase Fabz & 1.0 & 4.5 \\
\hline CPE1074 & CPF_1330 (accC) & acetyl-CoA carboxylase, biotin carboxylase & 1.7 & 4.9 \\
\hline CPE1075 & CPF_1331 (accD) & acetyl-CoA carboxylase, carboxyl transferase, beta subunit & 3.4 & 5.0 \\
\hline CPE1076 & CPF_1332 (accA) & acetyl-CoA carboxylase, carboxyl transferase, alpha subunit & 1.9 & 4.6 \\
\hline \multicolumn{5}{|c|}{ Protein synthesis } \\
\hline CPE1697 & CPF_1951 (frr) & ribosome recycling factor & 1.1 & 2.0 \\
\hline CPE2441 & CPF_2720 & ribosomal protein L7AE family & 1.1 & 2.6 \\
\hline CPE2660 & CPF_2997 (rpmH) & ribosomal protein L34 & 1.4 & 2.0 \\
\hline \multicolumn{5}{|c|}{ Purine, pyrimidine, nucleotides, and nucleosides } \\
\hline CPE1050 & CPF_1305 (mtnH) & 5-methylthioadenosine/S-adenosylhomocysteine nuclosidase & 3.2 & 2.6 \\
\hline CPE2162 & CPF_2418 (cpdC) & 2`,3`-cyclic-nucleotide $2^{`}$-phosphodiesterase & 3.4 & 1.6 \\
\hline \multicolumn{5}{|c|}{ Transport and binding proteins } \\
\hline CPE0977 & CPF_1235 & potassium transporter & 7.1 & 2.9 \\
\hline \multicolumn{5}{|c|}{ Unknown functions } \\
\hline CPE2601 & CPF_2928 & conserved hypothetical protein & 6.7 & 58.0 \\
\hline
\end{tabular}

All of the data are the means of three different experiments.

for both wild types and their mutants. The resistant mutants were more elongated than the wild types but the amounts of elongation and differences in cell shape were much more pronounced for the NCTR/NCTR ${ }^{R}$ strain pair than for the ATCC 13214/13124 ${ }^{\mathrm{R}}$ strain pair. Fluoroquinolone resistance selection also affected the colony morphology of the resistant strains. The colony size of $\mathrm{NCTR}^{\mathrm{R}}$ was bigger than that of the wild type, and the colony size of $13124^{\mathrm{R}}$ was smaller than that of the wild type (Additional file 4).

\section{Discussion}

The use of fluoroquinolones has been listed as a risk factor for the emergence of virulent antibiotic-resistant strains of some bacteria [21-23]. We studied the effect of fluoroquinolone resistance selection on the global 
Table 3 Microarray analysis of the genes that were downregulated in both gatifloxacin-resistant strains, $13124^{R}$ and NCTR ${ }^{R}$

\begin{tabular}{|c|c|c|c|c|}
\hline \multirow[t]{2}{*}{ Gene ID (name) } & & \multirow[t]{2}{*}{ Function/Similarity } & \multicolumn{2}{|c|}{ Microarray (mt/wt) } \\
\hline & & & NCTR & ATCC 13124 \\
\hline \multicolumn{5}{|c|}{ Biosynthesis of cofactors, prosthetic groups, and carriers } \\
\hline CPE1085 & CPF_1341 (ispH) & 4-hydroxy-3-methylbut-2-enyl diphosphate reductase & -2.4 & -2.2 \\
\hline \multicolumn{5}{|c|}{ Energy metabolism } \\
\hline CPE0292 & CPF_0288 & carbohydrate kinase family protein & -3.1 & -2.5 \\
\hline CPE1185 & CPF_1389 (pfk) & 6-phosphofructokinase & -1.7 & -2.7 \\
\hline CPE0585 & CPF_0565 (fruB) & fructose-1-phosphate kinase & -5.2 & -2.3 \\
\hline CPE0692 & CPF_0684 & transaldolase & -2.8 & -2.3 \\
\hline CPE0725 & CPF_0721 (nanl) ${ }^{*}$ & exo-alpha-sialidase & -3.5 & 1.5 \\
\hline CPE0894 & CPF_0887 (eutP) & ethanolamine utilization protein, EutP & -1.9 & -2.0 \\
\hline CPE2348 & CPF_2657 (ptb) & phosphate butyryltransferase & -2.3 & -1.6 \\
\hline \multicolumn{5}{|c|}{ Purine, pyrimidine, nucleotides, and nucleosides } \\
\hline CPE1398 & CPF_1652 (deoD) & purine nucleoside phosphorylase & -1.7 & -3.4 \\
\hline \multicolumn{5}{|c|}{ Regulatory functions } \\
\hline CPE0586 & CPF_0566 (fruR) & transcriptional regulator, DeoR family & -3.6 & -2.6 \\
\hline CPE0631 & CPF_0612 & probable PBP5 synthesis regulator protein & -2 & -2.5 \\
\hline CPE1077 & CPF_1333 & transcriptional regulator, PadR family & -3.1 & -3.2 \\
\hline CPE2510 & CPF_2833 & transcriptional regulator, PadR family & -2.6 & -2.7 \\
\hline CPE1305 & CPF_1512 & probable transcriptional regulator & -2 & -1.6 \\
\hline \multicolumn{5}{|c|}{ Transport and binding proteins } \\
\hline CPE0600 & CPF_0581 & amino acid $A B C$ transporter & -4.8 & -3.4 \\
\hline CPE1534 & CPF_1785 & PTS system, sucrose-specific IIBC component & -3.1 & -14.3 \\
\hline CPE2345 & CPF_2654 & putative maltose/maltodextrin $\mathrm{ABC}$ transporter & -2.0 & -1.8 \\
\hline \multicolumn{5}{|c|}{ Unknown functions } \\
\hline CPE2509 & CPF_2832 & degV family protein & -3.6 & -3.3 \\
\hline CPE1171 & CPF_1374 & mutator mutT protein homolog & -6.4 & -2.0 \\
\hline CPE2592 & CPF_2917 & phnA family protein & -2.8 & -2.0 \\
\hline
\end{tabular}

${ }^{*}$ Decrease in the expression of $n a n /$ in NCTR ${ }^{R}$ and increase of its expression in $13124^{R}$ was confirmed by qRT-PCR.

All of the data are the means of three different experiments.

transcriptional response in gatifloxacin-resistant $C$. their wild types. Many genes with similar functions were eiperfringens strains $13124^{\mathrm{R}}$ and $\mathrm{NCTR}^{\mathrm{R}}$ by microarray ana- $\quad$ ther upregulated or downregulated in the resistant mutants. lysis. The fluoroquinolone resistance selection resulted in However, some genes that were downregulated in $13124^{R}$ alteration of transcription levels of a significant number of were upregulated in NCTR ${ }^{R}$. qRT-PCR analysis confirmed genes involved in almost every aspect of metabolism in that the transcription of these genes, which included toxin the resistant mutants of both strains in comparison with genes for phospholipase C (PLC), perfringolysin O (PFO),

Table 4 Results of qRT-PCR for the $C$. perfringens regulatory genes in the wild types and mutants

\begin{tabular}{|c|c|c|c|c|}
\hline \multirow{2}{*}{\multicolumn{2}{|c|}{ Gene ID and name }} & \multirow[t]{3}{*}{ Regulatory function } & \multirow{2}{*}{\multicolumn{2}{|c|}{$\begin{array}{l}\text { qRT-PCR fold } \\
\text { change (mt/wt) }\end{array}$}} \\
\hline & & & & \\
\hline & & & \multirow{2}{*}{$\begin{array}{c}\text { NCTR } \\
7.4\end{array}$} & \multirow{2}{*}{$\frac{\text { ATCC13124 }}{1.3}$} \\
\hline CPE_1501 & CPF_1752 (virR) & DNA binding response regulator, VirR & & \\
\hline CPE_1500 & CPF_1751 (virS) & sensor histidine kinase, VirS & 9.7 & 0.3 \\
\hline CPE_0646 & CPF_0627 (virX) & conserved hypothetical protein & 2.2 & -3.0 \\
\hline CPE_0957 & CPF_1204 (vrr) & VR-RNA & 2.0 & -158.5 \\
\hline CPE_1701 & CPF_1955 (codY) & GTP-sensing transcriptional pleiotropic repressor CodY & 6.9 & -1.8 \\
\hline CPE_0073 & CPF_0069 & Transcription antiterminator & 1.5 & -116.5 \\
\hline CPE_0642 & CPF_0623 (RevR) & DNA binding response regulator & 2 & -2 \\
\hline
\end{tabular}



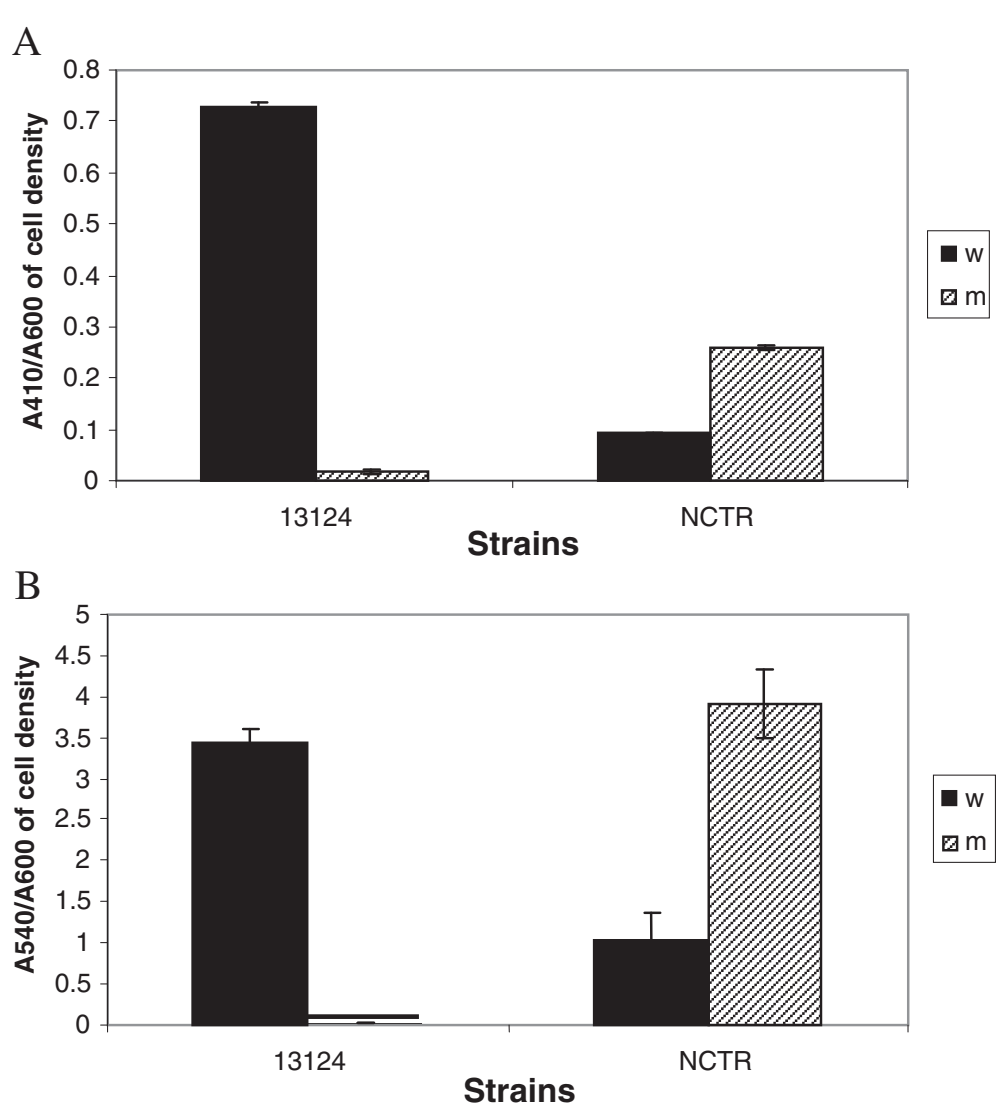

Figure 1 Comparison of phospholipase $C(A)$ and perfringolysin $O(B)$ activities of the wild type strains of $C$. perfringens, ATCC 13124 and NCTR, with their respective mutants, $13124^{R}$ and $N_{C T R}$. W: wild type, M: mutant.

collagenase and clostripain, were affected differently in the two mutants. Similarly, the production of these enzymes and the toxicity of the culture supernatants decreased in $13124^{\mathrm{R}}$ and increased in $\mathrm{NCTR}^{\mathrm{R}}$. It appears that gatifloxacin resistance selection resulted in alteration of global gene transcription in $C$. perfringens and that the effect was strain-specific.

The changes in the levels of global gene expression due to the response to fluoroquinolone exposure may be governed by complex regulatory processes. Both resistant strains harbored some common and some unique mutations in fluoroquinolone target genes. These enzymes are involved in the DNA supercoiling process that plays an essential role during gene transcription [38,39]. Although neither of the resistant strains was a clinical isolate, some of the mutations found in the resistant strains were the same as those found in fluoroquinolone-resistant mutants of $E$. coli obtained from clinical samples, which were also the same as those found in fluoroquinolone-resistant mutants of $E$. coli generated in the laboratory $[29,40]$.

The expression of a number of genes is affected by supercoiling [19] and aberrant expression of these genes occurs when DNA supercoiling has been altered by gyrase mutation(s). Alleles of gyrA that reduce DNA supercoiling have been shown to generate metabolic defects and reduce fitness of gyrase mutant strains $[38,41]$. Furthermore, because fluoroquinolones are DNA-damaging agents, in addition to inducing mutation in target genes, changing DNA superhelicity, they may also induce the expression of DNA repair genes via the SOS response, which may lead to phenotypic changes [15,17-20]. Cirz et al. [15] characterized the global transcription response of $S$. aureus to ciprofloxacin and, among other changes, found induction of the SOS response, upregulation of the TCA cycle and downregulation of $\alpha$-hemolysin and a leukocidin family toxin. The positive regulators of transcriptional responses for stress and toxin genes were also downregulated [15]. In C. perfringens, although the expression of several virulence genes decreased in one resistant mutant $\left(13124^{\mathrm{R}}\right)$, it increased in another $\left(\mathrm{NCTR}^{\mathrm{R}}\right)$. The transcription of various genes, including toxin genes, is regulated by virR and $\operatorname{virS}[32,42,43]$. VirS is a sensor histidine kinase, which autophosphorylates in response to extracellular signals, and VirR is a response regulator [32,42,43]. These two genes, along with vrr (which is an RNA regulator virR-RNA), are implicated in controlling gene transcription [44] and were 


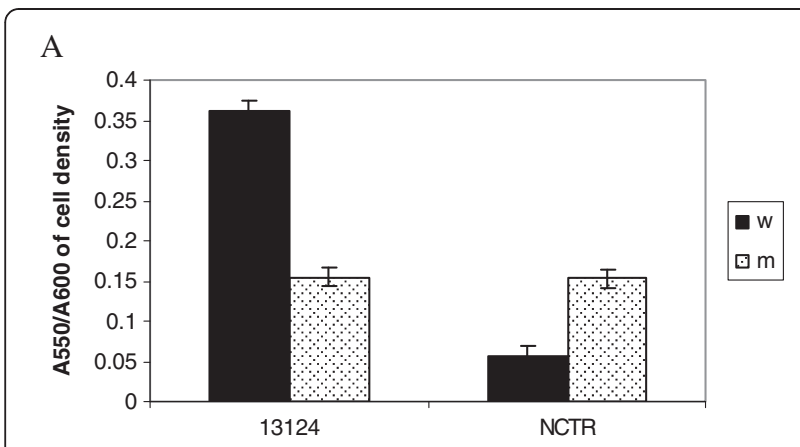

B

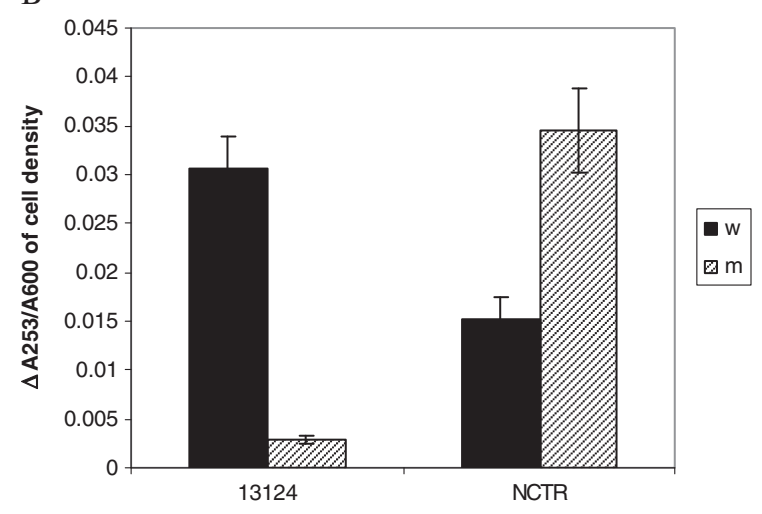

C

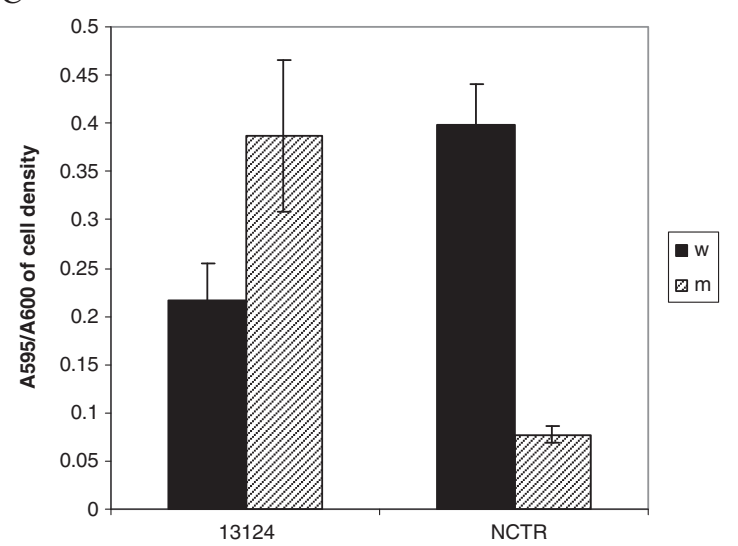

Figure 2 Comparison of collagenase (A), clostripain (B) and sialidase $(C)$ activities of the wild type strains of $C$. perfringens, ATCC 13124 and NCTR, with their respective mutants, $13124^{R}$ and $\mathrm{NCTR}^{\mathrm{R}}$. W: wild type, M: mutant.

upregulated in $\mathrm{NCTR}^{\mathrm{R}}$. In $13124^{\mathrm{R}}$, transcription of VirR did not change, and virS and vrr were downregulated. The gene $v r r$ is directly regulated by $\operatorname{VirR} / \mathrm{VirS}$, and as a regulatory RNA, controls transcription of 147 genes, including housekeeping and toxin genes, in C. perfringens [32,44]. Obana et al. [45] showed that VR-RNA regulates the stability of colA mRNA by cleaving the transcript. The processed shorter colA transcript was more stable than the longer intact $\operatorname{col} A$ transcript. It is possible that among other factors, downregulation of vrr in $13124^{R}(-158)$ may have

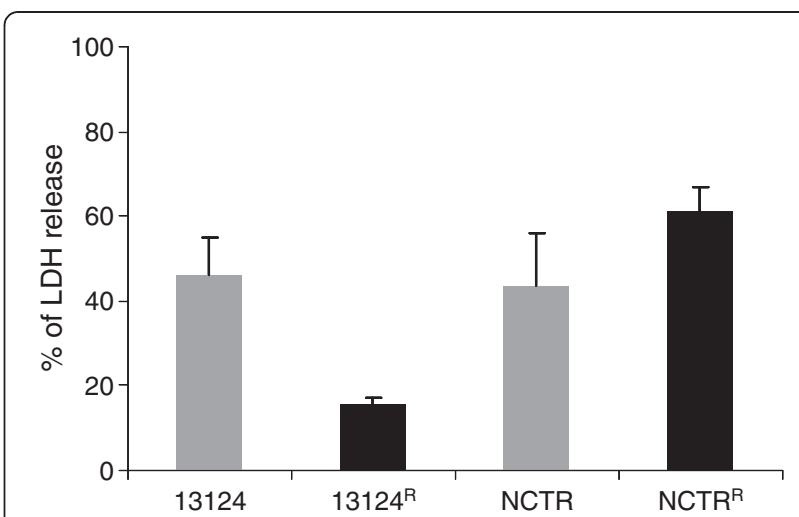

Figure 3 Comparison of cytotoxicity of two gatifloxacinresistant $C$. perfringens mutant strains, $13124^{R}$ and $N C T R^{R}$, with their wild type parents, strains ATCC 13124 and NCTR, for peritoneal macrophages, as measured by LDH (lactate dehydrogenase) released.

contributed to a decrease in the level of transcription of genes. The $v r r$ in $\mathrm{NCTR}^{\mathrm{R}}$ was upregulated twofold. vir $X$ is another regulatory gene that, even in the absence of the VirR/VirS regulatory system, activates the transcription of the $p f o A$, plc and colA genes, and its overexpression results in the increased expression of toxin genes $[44,46]$. qRTPCR results showed that the expression of this gene increased at least 2.2 times in $\mathrm{NCTR}^{\mathrm{R}}$ and decreased by -3.0 in $13124^{\mathrm{R}}$.

Another regulatory gene whose expression was altered in the mutants was $r e v R$, which was downregulated in $13124^{\mathrm{R}}$ and upregulated in $\mathrm{NCTR}^{\mathrm{R}}$. revR is a response regulator that alters the transcription of 100 genes, including those for potential virulence factors, which also are regulated by (VirR/VirS), and those for cell wall metabolism [47]. Hiscox et al. [47] found that a revR mutant of $C$. perfringens 13 was filamented. Gram staining of the wild types and mutants of ATCC 13124 and NCTR showed that cells of both mutants were filamented and longer than those of the wild types. Microarray and qRT-PCR analysis (Table 1) showed that some putative membrane protein genes were differentially expressed in the mutants and wild types of both strains.

The amino acid sequences of the toxin genes and the regulatory genes (virR/virS) in the mutants and wild types of both strains were identical, except that there were two silent mutations in virR/virS in $\mathrm{NCTR}^{\mathrm{R}}$, so the expression of toxin genes and their regulators was not the result of gene mutation. The sequence of $v r r$ was identical in the mutants and wild types of both strains, and the sequence of revR in ATCC 13124 and $13124^{R}$ was also identical. Obana and Nakamura [48] also detected other regulatory genes, CPE_1446-CPE_1447, which appear to regulate the transcription of $p l c, p f o A$, 
nanI and nagHIJK at transcription level. Microarray analysis showed that CPE_1447 was downregulated in NCTR ${ }^{\mathrm{R}}$, but this gene was not detected in the microarray data from ATCC 13124. qRT-PCR confirmed that nanI was downregulated and sialidase was decreased in $\mathrm{NCTR}^{\mathrm{R}}$; however, the role of CPE_1447 in the regulation of this gene is not clear.

Another global regulatory protein, CodY, has been shown to regulate expression of many genes in Bacillus subtilis and Clostridium difficile [49,50]. It appears to repress genes whose products are not needed during growth in high nutrient medium. qRT-PCR showed that CodY was upregulated (6.9 times) in $\mathrm{NCTR}^{\mathrm{R}}$ and downregulated $\left(-1.89\right.$ times) in $13124^{R}$. The sequence of $\operatorname{cod} Y$ was identical in both ATCC 13124 and $13124^{\mathrm{R}}$. Since both mutants and wild types were grown in a rich medium, the effect of CodY on alteration of gene expression in our strains is not known.

In addition, microarray analysis also detected some regulatory genes that were downregulated in both mutants (Table 3) and some that were upregulated in $\mathrm{NCTR}^{\mathrm{R}}$ and downregulated in $13124^{\mathrm{R}}$ (Table 1). Among those genes that were affected differently was CPF_0069, which is a transcription antiterminator similar to the BglG-type regulators in other bacteria (http://www.ncbi. nlm.nih.gov/). This gene was downregulated in $13124^{\mathrm{R}}$ and upregulated in $\mathrm{NCTR}^{\mathrm{R}}$. At this point, the roles that this gene and others play in altering the transcription of toxin genes in resistant strains are not known. Nor is there a reason known for the contradictory effects of fluoroquinolone resistance selection on the expression of regulatory genes, including those that regulate toxin production, and it needs to be investigated further. Autoinducers (AI-2) also have been implicated in the regulation of some toxin genes [51]. However, in our strains, the production of AI-2 per cell unit, measured by the indicator Vibrio harveyi, was higher for $13124^{\mathrm{R}}$ than for ATCC 13124 and lower for $\mathrm{NCTR}^{\mathrm{R}}$ than for NCTR. The ratio of AI-2 production per OD unit in an overnight culture of the mutant to that of the wild type was 1.5 for ATCC 13124 and 0.14 for NCTR. The contradictory results observed in the transcription of various toxin genes in two resistant strains were accompanied by changes in the levels of toxins and other enzymes. The most dramatic changes were observed for phospholipase C (PLC) and perfringolysin O (PFO). These two toxins were substantially decreased in $13124^{R}$ and increased in $\mathrm{NCTR}^{\mathrm{R}}$. The alterations in the production of enzymes were accompanied by changes in cytotoxicity for macrophages. The cytotoxicities of cell-free culture supernatants of the wild type ATCC 13124 and NCTR, for the macrophages were comparable. However, the cell-free culture supernatant of $13124^{\mathrm{R}}$ exhibited significantly lower cytotoxicity for macrophages than
ATCC 13124, but that of $\mathrm{NCTR}^{\mathrm{R}}$ had higher cytotoxicity than NCTR. These data were consistent with the alterations in the transcription patterns of toxin genes and enzyme assays that were observed by DNA microarray analysis, qRT-PCR assay and toxin production. The cytotoxic effects were correlated with the transcription pattern of toxins and virulence-associated genes and enzymatic activities, confirming that the effect of fluoroquinolones on $C$. perfringens was strain-specific. O'Brien and Melville [33] reported that perfringolysin O (PFO) plays a more prominent role than $\alpha$-toxin (PLC) in cytotoxicity for macrophages. Since we used the crude extract, which contains various factors including PFO and PLC, our results only show the alteration in the overall cytotoxicities of the mutants in comparison with their wild types and the contributing factors and their affinities for macrophage receptors are not known. Fluoroquinolone resistance selection decreased the toxicity of $13124^{\mathrm{R}}$ and increased the toxicity of $\mathrm{NCTR}^{\mathrm{R}}$.

\section{Conclusions}

Our study demonstrates that gatifloxacin resistance selection in C. perfringens was associated with upregulation or downregulation of different genes involved in various aspects of metabolism and that the effect was strain-specific. The genes involved in transcription regulation, virulence and cell toxicity were among those that were upregulated in one resistant strain and downregulated in another. Hiscox et al. [47] surmised that "the regulation of virulence in $C$. perfringens was a complex process" and we found that the nature of each strain adds yet another level of complexity to gene regulation in $C$. perfringens. Myer et al. [52] found widely variable large genomic islands in a large collection of C. perfringens strains and stated that considerable variation exists among the genomes of $C$. perfringens strains. It appears that this variation in gene structure of different $C$. perfringens strains also affects gene regulation and interaction of bacteria with fluoroquinolones. Fluoroquinolones have been implied to have a role in the development of $C$. difficile associated diarrhea [53]. Since virulent, drugresistant clinical isolates of pathogenic bacteria have an undefined genetic basis for their resistance and virulence, we used two wild types and otherwise isogenic resistant mutants, which are difficult to obtain in a clinical setting, to assess fluoroquinolone effects. Our results reflect clinical observations of finding fluoroquinolone-resistant strains of bacteria that are more or less virulent than the susceptible strains. They underscore the role of fluoroquinolones in changing bacterial virulence and the importance of prudent use of fluoroquinolones. Further study is needed on the effect of fluoroquinolones on a larger number of $C$. perfringens strains, along with genomic analysis of the resistant mutants. 


\section{Additional files}

\section{Additional file 1: Primers used for qRT-PCR. \\ Additional file 2: Analysis of mRNA quality and expression. \\ Additional file 3: Cytotoxicities of $C$. perfringens supernatants for macrophages.}

Additional file 4: Morphological examination of $C$. perfringens strains.

\section{Abbreviations}

PLC: Phospholipase C; PFO: Perfringolysin O; gyrA and gyrB: Gyrase; parC and parE: Topoisomerase IV; BHI: Brain Heart Infusion; VirS, VirR, virX, vrr(VR-RNA), Cody RevR: Regulatory genes.

\section{Competing interests}

The authors declare that they have no competing interests.

\section{Authors' contributions}

Technical experiments and statistical analysis were performed by MP and SP. SP performed those on RT-PCR and cytotoxicity, morphological analysis and MP performed the rest of the experiments. SP wrote the first draft of the manuscript sections on RT-PCR analysis, cytotoxicity and cell morphology. FR planned the experiments, analyzed the data, and wrote the manuscript. All authors have read and approved the final manuscript.

\section{Acknowledgments}

We thank Drs. Mark Hart and John B. Sutherland for their helpful comments on the manuscript, Dr. Carl E. Cerniglia for support of research and Drs. Donald Schwartz and Jean-Marie Rouillard for DNA microarray experiments. S.P. was supported by the FDA Commissioner's Fellowship Program. The views presented in this article do not necessarily reflect those of the US Food and Drug Administration.

\section{Author details}

'Division of Microbiology, National Center for Toxicological Research, US Food and Drug Administration, Jefferson, AR, USA. ${ }^{2}$ Current Address; W066 RM2467, 10903 New Hampshire Ave, Silver Spring, MD 20993-0002, USA.

Received: 31 August 2012 Accepted: 18 February 2013 Published: 1 March 2013

\section{References}

1. Scallan E, Hoekstra RM, Angulo FJ, Tauxe RV, Widdowson MA, Roy SL, et al: Foodborne illness acquired in the United States-major pathogens. Emerg Infect Dis 2011, 17:7-15.

2. Heimesaat MM, Granzow K, Leidinger H, Liesenfeld O: Prevalence of Clostridium difficile toxins $A$ and $B$ and Clostridium perfringens enterotoxin $A$ in stool samples of patients with antibiotic-associated diarrhea. Infection 2005, 33:340-344.

3. Meyns E, Vermeersch N, Ilsen B, Hoste W, Delooz H, Hubloue I: Spontaneous intrahepatic gas gangrene and fatal septic shock. Acta Chir Belg 2009, 109:400-404.

4. Rood JI: Virulence genes of Clostridium perfringens. Annu Rev Microbiol 1998, 52:333-360.

5. Sparks SG, Carman RJ, Sarker MR, McClane BA: Genotyping of enterotoxigenic Clostridium perfringens fecal isolates associated with antibiotic-associated diarrhea and food poisoning in North America. J Clin Microbiol 2001, 39:883-888.

6. Petit L, Gibert M, Popoff MR: Clostridium perfringens: toxinotype and genotype. Trends Microbiol 1997, 179:104-110.

7. Titball RW, Hunter SE, Martin KL, Morris BC, Shuttleworth AD, Rubidge T, et al: Molecular cloning and nucleotide sequence of the alpha-toxin (phospholipase C) of Clostridium perfringens. Infect Immun 1989, 57:367-376.

8. Lazarescu C, Kimmoun A, Blatt A, Bastien C, Levy B: Clostridium perfringens gangrenous cystitis with septic shock and bone marrow necrosis. Intensive Care Med 2012, 38:1906-1907.

9. Gosselink MP, Schouten WR, van Lieshout LM, Hop WC, Laman JD, et al: Eradication of pathogenic bacteria and restoration of normal pouch flora: comparison of metronidazole and ciprofloxacin in the treatment of pouchitis. Dis Colon Rectum 2004, 47:1519-1525.

10. Gionchetti P, Rizzello F, Venturi A, Ugolini F, Rossi M, Brigidi P, et al: Antibiotic combination therapy in patients with chronic, treatmentresistant pouchitis. Aliment Pharmacol Ther 1999, 13:713-718.

11. Leal J, Gregson DB, Ross T, Church DL, Laupland KB: Epidemiology of Clostridium species bacteremia in Calgary, Canada, 2000-2006. J Infect 2008, 5:198-203.

12. Wexler HM, Molitoris E, Finegold SM: In vitro activities of three of the newer quinolones against anaerobic bacteria. Antimicrob Agents Chemother 1992, 36:239-234.

13. Ferrero L, Cameron B, Crouzet J: Analysis of gyrA and grlA mutations in stepwise-selected ciprofloxacin-resistant mutants of Staphylococcus aureus. Antimicrob Agents Chemother 1995, 39:1554-1558.

14. Tamayo M, Santiso R, Gosalvez J, Bou G, Fernandez JL: Rapid assessment of the effect of ciprofloxacin on chromosomal DNA from Escherichia coli using an in situ DNA fragmentation assay. BMC Microbio/ 2009, 9:69.

15. Cirz RT, Jones MB, Gingles NA, Minogue TD, Jarrahi B, Peterson SN, et al: Complete and SOS-mediated response of Staphylococcus aureus to the antibiotic ciprofloxacin. J Bacteriol 2007, 189:531-539.

16. Dorr T, Lewis K, Vulic M: SOS response induces persistence to fluoroquinolones in Escherichia coli. PLoS Genet 2009, 5:e1000760.

17. Dorr T, Vulic M, Lewis K: Ciprofloxacin causes persister formation by inducing the TisB toxin in Escherichia coli. PLOS Biol 2010, 8:e1000317.

18. Dal Sasso M, Culici M, Bovio C, Braga PC: Gemifloxacin: effects of subinhibitory concentrations on various factors affecting bacterial virulence. Int J Antimicrob Agents 2003, 21:325-333.

19. Dorman CJ, Ni Bhriain N, Higgins CF: DNA supercoiling and environmental regulation of virulence gene expression in Shigella flexneri. Nature 1990, 344:789-792.

20. Mesak LR, Davies J: Phenotypic changes in ciprofloxacin-resistant Staphylococcus aureus. Res Microbiol 2009, 160:785-791.

21. Muto CA, Pokrywka M, Shutt K, Mendelsohn AB, Nouri K, Posey K, et al: A large outbreak of Clostridium difficile-associated disease with an unexpected proportion of deaths and colectomies at a teaching hospital following increased fluoroquinolone use. Infect Control Hosp Epidemiol 2005, 26:273-280.

22. Noren T: Clostridium difficile and the disease it causes. Methods Mol Biol 2010, 646:9-35

23. Pawlowski SW, Archbald-Pannone L, Carman RJ, Alcantara-Warren C, Lyerly D, Genheimer CW, et al: Elevated levels of intestinal inflammation in Clostridium difficile infection associated with fluoroquinolone-resistant $C$. difficile. J Hosp Infect 2009, 73:185-187.

24. Saxton K, Baines SD, Freeman J, O'Connor R, Wilcox MH: Effects of exposure of Clostridium difficile PCR ribotypes 027 and 001 to fluoroquinolones in a human gut model. Antimicrob Agents Chemother 2009, 53:412-420.

25. Uchida Y, Mochimaru T, Morokuma Y, Kiyosuke M, Fujise M, Eto F, et al: Clonal spread in Eastern Asia of ciprofloxacin-resistant Escherichia coli serogroup $\mathrm{O} 25$ strains, and associated virulence factors. Int J Antimicrob Agents 2010, 35:444-450

26. Drews SJ, Poutanen SM, Mazzulli T, McGeer AJ, Sarabia A, Pong-Porter S, et al: Decreased prevalence of virulence factors among ciprofloxacinresistant uropathogenic Escherichia coli isolates. J Clin Microbiol 2005, 43:4218-4220

27. Ferjani S, Saidani M, Ennigrou S, Hsairi M, Ben Redjeb S: Virulence determinants, phylogenetic groups and fluoroquinolone resistance in Escherichia coli isolated from cystitis and pyelonephritis. Pathol Biol (Paris) 2012, 60:270-274

28. Sun J, Hu J, Peng H, Shi J, Dong Z: Molecular and physiological characterization of fluoroquinolone resistance in relation to uropathogenicity among Escherichia coli isolates isolated from Wenyu River, China. Chemosphere 2012, 87:37-42.

29. Rafii F, Park M, Novak JS: Alterations in DNA gyrase and topoisomerase IV in resistant mutants of Clostridium perfringens found after in vitro treatment with fluoroquinolones. Antimicrob Agents Chemother 2005, 49:488-492.

30. Rafii F, Park M, Bryant AE, Johnson SJ, Wagner RD: Enhanced production of phospholipase $\mathrm{C}$ and perfringolysin $\mathrm{O}$ (alpha and theta toxins) in a gatifloxacin-resistant strain of Clostridium perfringens. Antimicrob Agents Chemother 2008, 52:895-900. 
31. Rafii F, Park M, Gamboa da Costa G, Camacho L: Comparison of the metabolic activities of four wild-type Clostridium perfringens strains with their gatifloxacin-selected resistant mutants. Arch Microbiol 2009, 191:895-902.

32. Ohtani K, Hirakawa H, Tashiro K, Yoshizawa S, Kuhara S, Shimizu T: Identification of a two-component VirR/VirS regulon in Clostridium perfringens. Anaerobe 2010, 16:258-264.

33. O'Brien DK, Melville SB: Effects of Clostridium perfringens alpha-toxin (PLC) and perfringolysin $\mathrm{O}$ (PFO) on cytotoxicity to macrophages, on escape from the phagosomes of macrophages, and on persistence of $C$. perfringens in host tissues. Infect Immun 2004, 72:5204-5215.

34. Awad MM, Ellemor DM, Bryant AE, Matsushita O, Boyd RL, Stevens DL, et al: Construction and virulence testing of a collagenase mutant of Clostridium perfringens. Microb Pathog 2000, 28:107-117.

35. Dargatz H, Diefenthal T, Witte V, Reipen G, von Wettstein D: The heterodimeric protease clostripain from Clostridium histolyticum is encoded by a single gene. Mol Gen Genet 1993, 240:140-145.

36. Li J, Sayeed S, Robertson S, Chen J, McClane BA: Sialidases affect the host cell adherence and epsilon toxin-induced cytotoxicity of Clostridium perfringens type D strain CN3718. PLoS Pathog 2011, 7:e1002429.

37. Song JM, Im JH, Hoon JH, Kang JD, Kang DJ: A simple method for hyaluronic acid quantification in culture broth. Carbohydr Polym 2009, 78:633-634.

38. Kugelberg E, Lofmark S, Wretlind B, Andersson DI: Reduction of the fitness burden of quinolone resistance in Pseudomonas aeruginosa. J Antimicrob Chemother 2005, 55:22-30.

39. Marcusson LL, Frimodt-Moller N, Hughes D: Interplay in the selection of fluoroquinolone resistance and bacterial fitness. PLoS Pathog 2009, 5:e1000541.

40. Bachoual R, Tankovic J, Soussy CJ: Analysis of the mutations involved in fluoroquinolone resistance of in vivo and in vitro mutants of Escherichia coli. Microb Drug Resist 1998, 4:271-276.

41. Smani Y, Lopez-Rojas R, Dominguez-Herrera J, Docobo-Perez F, Marti S, Vila $J$, et al: In vitro and in vivo reduced fitness and virulence in ciprofloxacinresistant Acinetobacter baumannii. Clin Microbiol Infect 2012, 18:1-4.

42. Shimizu T, Shima K, Yoshino K, Yonezawa K, Hayashi H: Proteome and transcriptome analysis of the virulence genes regulated by the VirR/VirS system in Clostridium perfringens. J Bacteriol 2002, 184:2587-2594.

43. Shimizu T, Yaguchi H, Ohtani K, Banu S, Hayashi H: Clostridial VirR/VirS regulon involves a regulatory RNA molecule for expression of toxins. Mol Microbiol 2002, 43:257-265.

44. Okumura K, Ohtani K, Hayashi H, Shimizu T: Characterization of genes regulated directly by the VirR/VirS system in Clostridium perfringens. J Bacteriol 2008, 190:7719-7727.

45. Obana N, Shirahama Y, Abe K, Nakamura K: Stabilization of Clostridium perfringens collagenase mRNA by VR-RNA-dependent cleavage in $5^{\prime}$ leader sequence. Mol Microbiol 2010, 77:1416-1428.

46. Ohtani K, Bhowmik SK, Hayashi H, Shimizu T: Identification of a novel locus that regulates expression of toxin genes in Clostridium perfringens. FEMS Microbiol Lett 2002, 209:113-118.

47. Hiscox TJ, Chakravorty A, Choo JM, Ohtani K, Shimizu T, Cheung JK, et al: Regulation of virulence by the RevR response regulator in Clostridium perfringens. Infect Immun 2011, 79:2145-2153.

48. Obana N, Nakamura K: A novel toxin regulator, the CPE1446-CPE1447 protein heteromeric complex, controls toxin genes in Clostridium perfringens. J Bacteriol 2011, 193:4417-4424.

49. Brinsmade SR, Sonenshein AL: Dissecting complex metabolic integration provides direct genetic evidence for CodY activation by guanine nucleotides. J Bacteriol 2011, 193:5637-5648.

50. Dineen SS, McBride SM, Sonenshein AL: Integration of metabolism and virulence by Clostridium difficile CodY. J Bacteriol 2010, 192:5350-5362.

51. Ohtani K, Yuan Y, Hassan S, Wang R, Wang Y, Shimizu T: Virulence gene regulation by the agr system in Clostridium perfringens. J Bacteriol 2009, 191:3919-3927.

52. Myers GS, Rasko DA, Cheung JK, Ravel J, Seshadri R, DeBoy RT, et al: Skewed genomic variability in strains of the toxigenic bacterial pathogen, Clostridium perfringens. Genome Res 2006, 16:1031-1040.
53. Deshpande A, Pant C, Jain A, Fraser TG, Rolston DD: Do fluoroquinolones predispose patients to Clostridium difficile associated disease? A review of the evidence. Curr Med Res Opin 2008, 24:329-333.

doi:10.1186/1471-2180-13-50

Cite this article as: Park et al:: Comparative transcription analysis and toxin production of two fluoroquinolone-resistant mutants of Clostridium perfringens. BMC Microbiology 2013 13:50.

\section{Submit your next manuscript to BioMed Central and take full advantage of:}

- Convenient online submission

- Thorough peer review

- No space constraints or color figure charges

- Immediate publication on acceptance

- Inclusion in PubMed, CAS, Scopus and Google Scholar

- Research which is freely available for redistribution

Submit your manuscript at www.biomedcentral.com/submit
C) BioMed Central 